\title{
Studies on the Survival and Growth of Fry of Catla catla (Hamilton, 1922) Using Live Feed
}

\author{
Abdul Kadhar, ${ }^{1}$ Arun Kumar, ${ }^{1}$ Jawahar Ali, ${ }^{1}$ and Akbar John ${ }^{2}$ \\ ${ }^{1}$ Unit of Aquaculture and Aquatic Toxicology, P.G \& Research Department of Zoology, The New College, Chennai 600014, India \\ ${ }^{2}$ Institute of Oceanography and Maritime (INOCEM), Kulliyyah of Science, International Islamic University Malaysia (IIUM), \\ Jalan Sultan Ahmad Shah, Bandar Indera Mahkota, 25200 Kuantan, Pahang, Malaysia
}

Correspondence should be addressed to Akbar John; akbarjohn50@gmail.com

Received 3 October 2013; Accepted 28 December 2013; Published 25 February 2014

Academic Editor: Ricardo Serrão Santos

Copyright (C) 2014 Abdul Kadhar et al. This is an open access article distributed under the Creative Commons Attribution License, which permits unrestricted use, distribution, and reproduction in any medium, provided the original work is properly cited.

Effect of live feed on the survival and growth of fry of Catla catla using three different live feeds namely, Cyclopoid (Thermocyclops decipiens), Cladoceran (Moina micrura), and mixed diet (Cyclopoid and Cladoceran) were studied. Commercial feed (Sunder's feed) was used as control. Feeding experiments were carried out in $100 \mathrm{~L}$ tanks for 40 days. Fish fry fed with the mixed diet showed significantly better survival rate $(54.80 \pm 2.43 \%)$ than those fed with other food types $(P<0.001)$. Fish fry fed with Cyclopoid had significantly $(P<0.001)$ better growth $(26.03 \pm 1.88 \mathrm{~mm}$, weight $61.07 \pm 3.53 \mathrm{mg})$ than those fed with other food types. Biochemical studies showed higher level of protein, carbohydrate, and lipid content in Catla fry fed with Cyclopoid diet. The results are discussed in the light of the literature available. It could be suggested that the Cyclopoid diet can be used as live feed for effective production of Catla fry.

\section{Introduction}

Availability of live food organisms in sufficient quantities is a major factor in the cultivation of early stages of shellfish and finfish. Only a few live feed organisms have been used in hatcheries [1]. In aquaculture, an increasing demand exists for live zooplankton in spite of the availability of Artemia nauplii and rotifers [2-4]. The zooplankton forms ideal food usually in the larval stages of prawns and in early larval stages of fishes [5]. Zooplankton are the preferred food of fishes, particularly, fry and fingerling stage [6]. Being a natural food of fish and prawn larvae, zooplankton collected from natural resources are used as diet for the larvae of ornamental fish in many hatcheries [7].

Zooplankton have been widely used for rearing fish larval stages, and most studies indicated that the fry performed better when fed live zooplankton than dry artificial diets $[8,9]$. In larviculture, artificial diet may perform poorly due to poor digestibility and deficiency of growth factors [10]. Common carp and Atlantic salmon grew faster when fed on zooplankton than those fed on formulated diets [11]. Many authors have emphasized zooplankton as live food in general, particularly, Copepods and Cladoceran [12-16]. Nutritional quality of Copepods is reported to have high protein content and a good amino acid profile. The fatty acid composition with regard to HUFA is high in Copepods [17]. Zooplankton growth in nature may depend on the quality of the food available as the phytoplankton community changes. Phytoplankton may stimulate zooplankton development by production of vitamin $\mathrm{E}$ ( $\alpha$-tocopherol) and releasing "odour" into water [18]. Feeding rates of zooplankton are mainly dependent on food concentration, food quality, and water temperature $[19,20]$. It has been shown by several workers that feeding among Copepods was related to chemoreceptors [21, 22], mechanoreceptors [23] and taste of the particular food [24].

The Cladocerans are considered to be suitable live feed for fish larvae and they were mass cultured successfully by many investigators, using different cheap organic waste products [9, 25-27]. Daphnia are small freshwater Cladoceran crustaceans commonly called "water fleas." This common name is 
the result of not only their size but also their short, jerky, and hopping movement in water. The genera Daphnia and Moina are closely related.

Moina is a common and widely distributed freshwater cladoceran. Adult Moina are longer than newly hatched brine shrimp and approximately two to three times the length of adult rotifers. However, young Monia are approximately the same size as or only slightly larger than adult rotifers and smaller than newly hatched brine shrimp. In addition, brine shrimp die quickly in fresh water. As a result, Moina are ideally suited for feeding freshwater fish fry. Newly hatched fry of most freshwater fish species can ingest young Moina as their initial food [28].

Copepods are microscopic zooplankton inhabiting both fresh water and marine environment. They include free living orders: Calanoida, Cyclopoida, and Harpacticoid. Of these three, Calanoids and Cyclopoids are more dominant than Harparcticoids (Alfred et al., 1973). Copepods are the most important components of aquatic ecosystem and play vital role as primary consumers. This group directly transfers energy from primary producers to secondary consumers. They range in size from less than $1 \mathrm{~mm}$ to more than $5 \mathrm{~mm}$. In the aquatic habitat, their small size is compensated by their occurrence in large numbers [29]. Copepods are the dominant and most abundant secondary producers among marine and fresh water zooplankton and hence are of major ecological significance [30]. They are an excellent food of high nutritional value for zooplanktivorous fish and shrimps [31]. Copepods constitute an important component of the food chain in aquatic systems. The nutritional quality of Copepods is accepted to be highly satisfactory for larvae of prawn and finfish species. Biochemical studies have shown that Copepods are rich in proteins, lipids, essential amino acids (EAAs), and essential fatty acids (EFAs), which can provide enhanced reproduction of brood stock, augmented growth, immune stimulation, and color enhancement in prawns and fishes $[13,16]$. Copepods show wide occurrence from wild sources throughout the year [32, 33]. However, fluctuations in quality and quantity and drawbacks of collecting methods are major problems for their commercial utilization. In view of the growing needs for the production of large quantities of larval shrimp and fish for aquacultural practices, the culture of Copepods has been attempted [31]. Copepods constitute important live food in the rearing of larvae of fishes $[34,35]$. Many authors have reported the utilization of Copepods from wild and cultured sources for higher yields of prawns in ponds [36-38]. Cyclopoid Copepods are physically diminutive, yet their presence in aquatic system can be great. Cyclopoids usually range in length from 0.5 to $2.0 \mathrm{~mm}$ and are primarily benthic, although a few species thrive in the pelagic zones of lakes, seas, and oceans. Within these larger bodies of water, Cyclopoid biodiversity tends to be the highest in the littoral zone. Their diversity and abundance can also be great in shallower bodies of water, such as wetlands and temporary ponds [39]. Some species are euryhaline and occur in brackish water and fresh water [40]. Cyclopoid copepod plays an important role in aquatic food webs as either primary consumers or predators. They can also be an important source of food for larval, juvenile, and adult fish of many species.
The aim of the present study was to evaluate the effect of three different live feed organisms such as Cyclopoid (T. decipiens), Cladocerans (M. micrura), and mixed diet (Cyclopoid and Cladoceran) on the survival, growth, and the biochemical composition of the fry of Catla catla.

\section{Materials and Methods}

Fry of Catla was obtained from Tamil Nadu Fisheries Department Seed Farm at Bhavanisagar, Tamil Nadu, in May 2011 and were maintained in the laboratory for further studies. For fry rearing and feeding experiments, freshly hatched out early fry stages (average length $6.10 \pm 0.10 \mathrm{~mm}$ and average weight: $10.37 \pm 0.25 \mathrm{mg}$ ) were carefully selected. Fry rearing and feeding experiments on C. catla were conducted with different feeds. Artificial pelletized commercial feed (Saunders's feed with proximate composition of protein $60 \%$, lipid $20 \%$, carbohydrate $10 \%$, ash $8 \%$, and moisture $5 \%$ ) served as control feed. The Cladoceran, M. micrura, and the copepod, T. decipiens, were fed separately as well as in the form of mixed feed (50\% M. micrura and 50\% T. decipiens) which constitutes an experimental diet. A batch of 250 early fry of C. catla of similar length were introduced in the cement experimental tank $(75 \mathrm{~cm}$ (length) $\times 40 \mathrm{~cm}$ (diameter) in 35 liters of water) for control as well as experimental diet. The experiments were repeated to obtain triplicate values. The fry of $C$. catla commenced their exogenous feeding on the 4 th and 5th day, respectively. Food was offered to the different batches of Catla fry at the rate of $30 \%$ of their body weight in a similar schedule of 3 times a day ( $7 \mathrm{am}, 2 \mathrm{pm}$, and $6 \mathrm{pm}$ ) and experiments were conducted for 40 days. During the course of experiment, increased feed was offered as per the following formula [9]:

Feed increase $=$ average body wt.

$$
\times \text { approximate survival } \times \% \text { of body wt. }
$$

During experimental period, water temperature and $\mathrm{pH}$ were recorded daily and were found in normal range $(26 \pm$ $1^{\circ} \mathrm{C}$ and $\mathrm{pH}$ 6.8-7.1). Other physicochemical parameters such as dissolved oxygen, calcium, magnesium, total hardness, alkalinity, ammonia, nitrite, nitrate, phosphate, sulphate, and chloride were analyzed on stocking day, 8th, 16th, 24th, 32nd, and 40th day following the procedures of APHA (1998) and IAAB (1998). Daily at morning hours, excess feed and fecal matter were removed from the fry rearing tank and $50 \%$ of water was replenished. Except during water exchange and feeding time, the fry rearing tank was continuously aerated. Length and weight of the fry from all tanks were recorded every day for 12 days and then on the $17 \mathrm{th}, 24 \mathrm{th}, 31 \mathrm{st}, 37 \mathrm{th}$, and 40th day of experiments. Survivals of fry of both the fishes were calculated on the 8th, 16th, 24th, 32nd, and 40th day. Percentage survival (\%) was calculated (dead fishes were removed). At the end of the experiments, analysis of bodyhomogenate of the fry of Catla was carried out for protein[41], carbohydrate 6 [42], and lipid [43].

Mean and standard deviation were calculated for length and weight, body weight gain, survival, and SGR (specific 
TABLE 1: Growth parameters of C. catla fry fed with different diets (mean \pm SD).

\begin{tabular}{|c|c|c|c|c|c|c|}
\hline Type of feed & $\begin{array}{l}\text { Initial length } \\
(\mathrm{mm})\end{array}$ & $\begin{array}{l}\text { Final length } \\
(\mathrm{mm})\end{array}$ & $\begin{array}{l}\text { Initial Weight } \\
\text { (mg) }\end{array}$ & $\begin{array}{l}\text { Final Weight } \\
(\mathrm{mg})\end{array}$ & $\begin{array}{l}\text { Weight gain } \\
\text { (mg) }\end{array}$ & SGR \\
\hline Control & $6.17 \pm 0.06^{\mathrm{ab}}$ & $14.77 \pm 1.63^{\mathrm{a}}$ & $10.80 \pm 0.20^{\mathrm{b}}$ & $21.83 \pm 3.33^{\mathrm{a}}$ & 11.03 & 0.027 \\
\hline Cyclopoid & $6.30 \pm 0.10^{\mathrm{bc}}$ & $26.03 \pm 1.88^{\mathrm{c}}$ & $10.77 \pm 0.15^{\mathrm{b}}$ & $61.07 \pm 3.53^{c}$ & 50.30 & 0.125 \\
\hline Cladoceran & $6.43 \pm 0.12^{c}$ & $22.11 \pm 1.57^{\mathrm{b}}$ & $11.30 \pm 0.17^{\mathrm{c}}$ & $44.17 \pm 2.75^{\mathrm{b}}$ & 32.87 & 0.082 \\
\hline Cyclopoid and Cladoceran & $6.10 \pm 0.10^{\mathrm{a}}$ & $25.0 \pm 1.32^{\mathrm{bc}}$ & $10.37 \pm 0.25^{\mathrm{a}}$ & $49.03 \pm 2.67^{b}$ & 38.66 & 0.096 \\
\hline$F$ value & 7.152 & 25.775 & 11.199 & 84.466 & & \\
\hline$P$ value & 0.012 & $0.000^{* *}$ & $0.003^{* *}$ & $0.000^{* *}$ & & \\
\hline
\end{tabular}

Note. $^{* *}$ and ${ }^{*}$ denote significant level at $99 \%$ and $95 \%$ confident level, respectively. Different alphabet between types of feed denotes significant at $95 \%$ confidant level using Duncan Multiple Range Test (DMRT).

TABLE 2: Survival percentage (\%) of Catla fry fed with different diets (mean \pm SD).

\begin{tabular}{lccccc}
\hline Type of feed & \multicolumn{4}{c}{ Days } & \\
& 8 & 16 & 24 & 32 & 40 \\
\hline Control & $83.73 \pm 3.84^{\mathrm{a}}$ & $64.93 \pm 1.51^{\mathrm{bc}}$ & $49.07 \pm 2.01^{\mathrm{a}}$ & $40.27 \pm 1.80^{\mathrm{a}}$ & $36.67 \pm 3.11^{\mathrm{a}}$ \\
Cyclopoid & $82.00 \pm 1.44^{\mathrm{a}}$ & $62.13 \pm 4.39^{\mathrm{b}}$ & $55.60 \pm 4.06^{\mathrm{b}}$ & $57.60 \pm 8.66^{\mathrm{b}}$ & $43.33 \pm 0.46^{\mathrm{b}}$ \\
Cladoceran & $82.67 \pm 2.05^{\mathrm{a}}$ & $65.87 \pm 3.78^{\mathrm{bc}}$ & $58.67 \pm 4.11^{\mathrm{bc}}$ & $53.60 \pm 3.27^{\mathrm{b}}$ & $49.33 \pm 3.23^{\mathrm{c}}$ \\
Cyclopoid and Cladoceran & $85.07 \pm 1.85^{\mathrm{a}}$ & $68.93 \pm 1.15^{\mathrm{d}}$ & $63.33 \pm 2.01^{\mathrm{d}}$ & $58.53 \pm 1.89^{\mathrm{b}}$ & $54.80 \pm 2.43^{\mathrm{d}}$ \\
\hline$F$ value & 0.879 & 2.537 & 10.361 & 9.214 & 27.861 \\
$P$ value & 0.491 & 0.130 & $0.004^{* *}$ & $0.006^{* *}$ & $0.000^{* *}$ \\
\hline
\end{tabular}

Note. ${ }^{* *}$ and ${ }^{*}$ denote significant level at $99 \%$ and $95 \%$ confident level, respectively. Different alphabet between types of feed denotes significant at $95 \%$ confidant level using Duncan Multiple Range Test (DMRT).

growth rate) of the fry Catla in different feeding regimes. Body weight gain, survival, and SGR were calculated using the formula given by Aliyu-Paiko et al. (2010) [44]:

$$
\text { Wt. gain }(\mathrm{WG} \%)=\left\{\frac{\left(W_{f}-W_{i}\right)}{W_{i}}\right\} \times 100 \text {, }
$$

Percentage survival $=\frac{\text { final number of surviving fish }}{\text { initial number of fish }} \times 100$, Specific growth rate $(\mathrm{SGR})=\left\{\frac{\left(\ln W_{f}-\ln W_{i}\right)}{T}\right\} \times 100$,

where $W_{f}$ is final weight, $W_{i}$ is initial weight, and $T$ is time (number of days).

\section{Results}

Overall growth parameters of Catla fry fed with different feeding regimes are shown in Table 1 . The growth parameters pertaining to length and weight showed highest increase in Cyclopoid fed fry. The minimum increase was observed in Cladoceran fed fry. Moderate growth was observed in mixed diet. The length of Catla fry increased from $6.30 \pm 0.10 \mathrm{~mm}$ to $26.03 \pm 1.88 \mathrm{~mm}$ in Cyclopoid diet followed by mixed diet where the initial length was $6.10 \pm 0.10$ and final length was $25 \pm 1.32 \mathrm{~mm}$. In Cladoceran diet, Catla fry increased in length from $6.43 \pm 0.12$ to $22.11 \pm 1.57$ during the study period. The control diet fed Catla fry (Saunders' feed) showed increase in length from $6.17 \pm 0.06$ to $14.77 \pm 1.63 \mathrm{~mm}$. Similar trends were observed with respect to weight. The Cyclopoid diet fed Catla fry recorded the maximum weight gain of $50.3 \mathrm{mg}$ followed by $38.66 \mathrm{mg}$ in mixed diet, $32.87 \mathrm{mg}$ in Cladoceran diet, and only $11.03 \mathrm{mg}$ in the control diet (Table 1).

SGR values of Catla fry were higher in Cyclopoid diet (0.13), followed by mixed diet (0.09), in Cladoceran diet (0.08) and in control (0.03). It is clear that Cyclopoid diet showed higher SGR in Catla fry followed by mixed diet. However, the highest survival rate of Catla fry after 40 days was recorded in mixed diet $(54.8 \%)$, followed by Cladoceran diet $(49.33 \%)$ and Cyclopoid diet (43.33\%) when compared to that of control diet (36.67\%) (Table 2). Statistical analysis revealed that the effects of 3 diets on length and weight of Catla fry are significantly different $(P<0.001)$.

The biochemical parameters of fry of Catla fed with different feeding regimes are given in Figure 1. It is evident that the carcass composition of Catla fry showed highest protein, carbohydrate, and lipid levels in Cyclopoid diet followed by mixed diet and least in Cladoceran diet. Protein level in the fry of Catla was $4.00 \pm 0.15 \mathrm{mg} / \mathrm{gm}$ in Cyclopoid diet followed by mixed diet $(4.00 \pm 0.10 \mathrm{mg} / \mathrm{gm})$. In Cladoceran diet, it was $3.69 \pm 0.12 \mathrm{mg} / \mathrm{gm}$ compared to $2.817 \pm$ $0.10 \mathrm{mg} / \mathrm{gm}$ in control diet. With respect to carbohydrate, the highest levels were obtained in control diet $(0.94 \pm$ $0.03 \mathrm{mg} / \mathrm{gm})$ and Cyclopoid $\operatorname{diet}(0.90 \pm 0.03 \mathrm{mg} / \mathrm{gm})$. In the fry fed Cladoceran diet, the carbohydrate content was $0.84 \pm 0.02 \mathrm{mg} / \mathrm{gm}$, whereas, in the mixed diet, it was $0.82 \pm$ $0.02 \mathrm{mg} / \mathrm{gm}$. Lipid composition of Catla fry was the highest in 
TABLE 3: Level of dissolved oxygen $(\mathrm{mg} / \mathrm{L})$ in the rearing tanks of Catla fry (mean $\pm \mathrm{SD})$.

\begin{tabular}{|c|c|c|c|c|c|c|}
\hline \multirow{2}{*}{ Type of feed } & \multicolumn{6}{|c|}{ Days } \\
\hline & 1 & 8 & 16 & 24 & 32 & 40 \\
\hline Control & $4.47 \pm 0.07$ & $4.60 \pm 0.10^{\mathrm{a}}$ & $4.93 \pm 0.15^{\mathrm{ab}}$ & $5.30 \pm 0.10^{\mathrm{d}}$ & $5.07 \pm 0.32^{\mathrm{b}}$ & $4.65 \pm 0.05$ \\
\hline Cyclopoid & $4.50 \pm 0.10$ & $4.80 \pm 0.10^{\mathrm{b}}$ & $4.90 \pm 0.10^{\mathrm{a}}$ & $4.30 \pm 0.10^{\mathrm{b}}$ & $4.30 \pm 0.10^{\mathrm{a}}$ & $3.98 \pm 0.10$ \\
\hline Cladoceran & $4.50 \pm 0.05$ & $4.80 \pm 0.05^{\mathrm{b}}$ & $5.10 \pm 0.05^{\mathrm{bc}}$ & $4.07 \pm 0.13^{\mathrm{a}}$ & $4.10 \pm 0.05^{\mathrm{a}}$ & $4.20 \pm 0.05$ \\
\hline Cyclopoid and Cladoceran & $4.50 \pm 0.05$ & $4.70 \pm 0.05^{\mathrm{b}}$ & $5.15 \pm 0.05^{b c}$ & $4.60 \pm 0.05^{\mathrm{c}}$ & $4.75 \pm 0.05^{\mathrm{b}}$ & $3.90 \pm 0.05$ \\
\hline$F$ value & 0.109 & 4.400 & 4.717 & 89.739 & 19.331 & 73.818 \\
\hline$P$ value & 0.953 & 0.042 & 0.034 & $0.000^{* *}$ & $0.001^{* *}$ & $0.000^{* *}$ \\
\hline
\end{tabular}

Note. ${ }^{* *}$ and ${ }^{*}$ denote significant level at $99 \%$ and $95 \%$ confident level, respectively. Different alphabet between types of feed denotes significant at $5 \%$ level using Duncan Multiple Range Test (DMRT).

TABLE 4: Level of calcium $(\mathrm{mg} / \mathrm{L})$ in the rearing tanks of Catla fry (mean $\pm \mathrm{SD})$.

\begin{tabular}{|c|c|c|c|c|c|c|}
\hline \multirow{2}{*}{ Type of feed } & \multicolumn{6}{|c|}{ Days } \\
\hline & 1 & 8 & 16 & 24 & 32 & 40 \\
\hline Control & $34.00 \pm 1.00$ & $35.00 \pm 1.25^{\mathrm{a}}$ & $35.00 \pm 1.25^{\mathrm{a}}$ & $40.00 \pm 1.50^{\mathrm{d}}$ & $41.00 \pm 1.50^{c}$ & $48.00 \pm 1.80^{\mathrm{d}}$ \\
\hline Cyclopoid & $34.00 \pm 1.00$ & $39.00 \pm 1.50^{\mathrm{b}}$ & $36.00 \pm 1.30^{\mathrm{a}}$ & $31.00 \pm 1.10^{\mathrm{a}}$ & $38.00 \pm 1.40^{\mathrm{b}}$ & $41.00 \pm 1.50^{c}$ \\
\hline Cladoceran & $34.00 \pm 1.00$ & $38.00 \pm 1.40^{\mathrm{b}}$ & $42.00 \pm 1.60^{\mathrm{b}}$ & $33.00 \pm 1.0^{\mathrm{b}}$ & $36.00 \pm 1.30^{\mathrm{a}}$ & $35.00 \pm 1.25^{\mathrm{a}}$ \\
\hline Cyclopoid and Cladoceran & $34.00 \pm 1.00$ & $38.00 \pm 1.40^{\mathrm{b}}$ & $36.00 \pm 1.30^{\mathrm{a}}$ & $38.00 \pm 1.40^{c}$ & $42.00 \pm 1.60^{c}$ & $37.67 \pm 1.53^{\mathrm{b}}$ \\
\hline$F$ value & 0.000 & 9.000 & 30.750 & 53.000 & 22.750 & 71.062 \\
\hline$P$ value & 1.000 & $0.006^{* *}$ & $0.000^{* *}$ & $0.000^{* *}$ & $0.000^{* *}$ & $0.000^{* *}$ \\
\hline
\end{tabular}

Note. $^{* *}$ and ${ }^{*}$ denote significant level at $99 \%$ and $95 \%$ confident level, respectively. Different alphabet between types of feed denotes significant at $5 \%$ level using Duncan Multiple Range Test (DMRT).

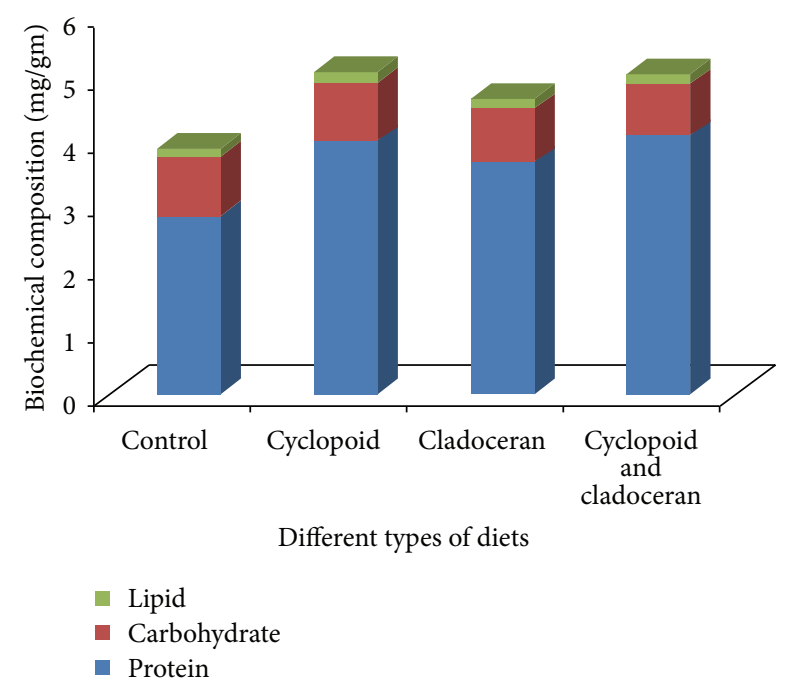

FIGURE 1: Level of carbohydrate, protein, and lipid of Catla fry fed with different diets.

Cyclopoid diet $(0.16 \pm 0.00 \mathrm{mg} / \mathrm{gm})$. In the fry fed with mixed diet and Cladoceran diet, it was $0.14 \pm 0.01 \mathrm{mg} / \mathrm{gm}$, whereas, in the control diet, it was $0.12 \pm 0.06 \mathrm{mg} / \mathrm{gm}$.

Chemical parameters of the water samples of Catla fry rearing tanks are shown in Tables 3 and 4 . The dissolved oxygen content in the fish fry rearing tank with Cyclopoid diet ranged between 3.98 and $4.90 \mathrm{mg} / \mathrm{L}$. As shown in Table 3, the calcium content of the water sample showed gradual increase and attained maximum level $(48 \mathrm{mg} / \mathrm{L})$ on the 40 th day of experiment with control diet and the Cyclopoid diet showed the maximum $(41.00 \mathrm{mg} / \mathrm{L})$. All other chemical parameters (magnesium, total hardness, alkalinity, ammonia, nitrite, nitrate, phosphate, sulphate, and chloride) showed a narrow fluctuation during the period of experimentation. The chemical parameters of the fry rearing tank with Cladoceran diet occurred in normal range and the values did not vary widely during the different period of the experiment. In the fry rearing tank with Cyclopoid and Cladoceran diet, the dissolved oxygen showed narrow fluctuation during the course of experimentation. All other parameters showed a very narrow range of fluctuation.

Pearson correlation matrix showed weak correlation coefficient value " $\mathrm{r}$ " for most of the parameters in Catla fry rearing tank. However, high positive correlation $(r=0.704)$ was recorded between phosphate and chloride, sulphate and chloride $(r=0.673)$, and calcium and chloride $(r=0.539)$. Ammonia and nitrite showed a moderate positive correlation $(r=0.440)$.

Correlation between dissolved oxygen and survival of Catla fry had a positive correlation $(r=0.063)$. Similarly, positive correlation was obtained between the level of magnesium and survival of Catla fry $(r=0.386)$. Negative correlation between sulphate and survival was observed $(r=$ $-0.741)$ and nitrate and Catla fry survival was recorded $(r=$ -0.410) (Table 5). All other water quality chemical parameters and survival rate showed negative correlation.

\section{Discussion}

In intensive rearing of fish larvae, feeding constitutes the major factor, since fish obtain their entire nutritional requirement through the food consumed [45]. Various studies 
TABLE 5: Correlation coefficient between different water quality parameters in the Catla fry rearing tanks.

\begin{tabular}{|c|c|c|c|c|c|c|c|c|c|c|c|}
\hline & $\begin{array}{c}\text { Dissolved } \\
\text { oxygen }\end{array}$ & Calcium & Magnesium & $\begin{array}{c}\text { Total } \\
\text { hardness }\end{array}$ & Alkalinity & Ammonia & Nitrite & Nitrate & Phosphate & Sulphate & Chloride \\
\hline $\begin{array}{l}\text { Dissolved } \\
\text { oxygen }\end{array}$ & 1.000 & $0.314^{* *}$ & $-0.412^{* *}$ & -0.183 & $-0.242^{*}$ & 0.070 & -0.013 & 0.094 & -0.166 & -0.022 & $0.243^{*}$ \\
\hline Calcium & - & 1.000 & $-0.274^{*}$ & $0.432^{* *}$ & $0.336^{* *}$ & $0.379^{* *}$ & 0.117 & 0.196 & $0.502^{* *}$ & $0.528^{* *}$ & $0.539^{* *}$ \\
\hline Magnesium & - & - & 1.000 & -0.065 & -0.004 & $-0.273^{*}$ & -0.100 & $0.329^{* *}$ & -0.071 & -0.197 & $-0.491^{* *}$ \\
\hline $\begin{array}{l}\text { Total } \\
\text { hardness }\end{array}$ & - & - & - & 1.000 & $0.671^{* *}$ & $0.597^{* *}$ & 0.193 & 0.068 & $0.698^{* *}$ & $0.584^{* *}$ & $0.456^{* *}$ \\
\hline Alkalinity & - & - & - & - & 1.000 & $0.642^{* *}$ & $0.577^{* *}$ & -0.055 & $0.514^{* *}$ & $0.598^{* *}$ & $0.471^{* *}$ \\
\hline Ammonia & - & - & - & - & - & 1.000 & $0.440^{* *}$ & -0.045 & $0.576^{* *}$ & $0.662^{* *}$ & $0.605^{* *}$ \\
\hline Nitrite & - & - & - & - & - & - & 1.000 & 0.055 & 0.095 & $0.371^{* *}$ & 0.181 \\
\hline Nitrate & - & - & - & - & - & - & - & 1.000 & -0.023 & 0.169 & 0.217 \\
\hline Phosphate & - & - & - & - & - & - & - & - & 1.000 & $0.683^{* *}$ & $0.704^{* *}$ \\
\hline Sulphate & - & - & - & - & - & - & - & - & - & 1.000 & $0.673^{* *}$ \\
\hline Chloride & - & - & - & - & - & - & - & - & - & - & 1.000 \\
\hline
\end{tabular}

Note. ${ }^{* *}$ and ${ }^{*}$ denote significant level at $99 \%$ and $95 \%$ confident level, respectively.

highlight the fact that fish and prawn larvae prefer live feed compared to formulated feed [46-48]. Nutritional status of live feed further enhanced by 7 bioenrichment and therefore the nutritional status of fishes and prawn can be increased. In the present study, it is clearly evident that Catla fry showed significant increase in growth parameters, survival, SGR, FCR, and protein, when fed with live feed like Cyclopoid singly or combination of Cyclopoid and Cladoceran which is in agreement with the previous reports [47, 49]. It is possible that growth increment seen in Catla fry in the present study could be due to high protein content and amino acid profile of live feed organism reported earlier [47]. In the present study, it was demonstrated that both control feed (artificial pellets) and live feeds were accepted by the fry of both the fishes as evidenced by their development of late fry stage. These diets supported varying degrees of growth and survival of the fish fry in a forty-day fry rearing experiment. Further, results of present study suggest that fry rearing up to late fry stage is better with live feed than the control (artificial pellets) as evidenced by the higher growth and survival of the fry of Catla.

With regard to the chemical parameters of the culture system, higher dissolved oxygen content was recorded in the rearing system of Catla fry with Cladoceran as the live feed. Dissolved oxygen levels are improved due to photosynthesis, while ammonia levels are reduced through assimilation by phytoplankton. Different levels of dissolved oxygen content were reported in fish rearing system of larvae of Cyprinus carpio $(8.77 \mathrm{mg} / \mathrm{L}$ to $10.85 \mathrm{mg} / \mathrm{L})$ [49]. Generally, cyprinids are capable of tolerating low oxygen levels of $3 \mathrm{mg} / \mathrm{L}$ [50]. The level of dissolved oxygen content in the Catla fry rearing system of present study was found between $3.9 \mathrm{mg} / \mathrm{L}$ and $5.3 \mathrm{mg} / \mathrm{L}$. This level of dissolved oxygen is adequate to promote normal growth and development [51]. It is interesting to note that with similar intensity and duration of aeration, lower dissolved oxygen content in the koi carp tanks might be due to their higher oxygen consumption which is indicative of higher metabolism in the larvae of koi carp than the goldfish [9].

Temperature is one of the important parameters, which has a definitive influence on the growth and duration of larval period of carps. In the present study, even though better development of Catla fry was recorded in a temperature range of $30 \pm 2^{\circ} \mathrm{C}$ to $32 \pm 1^{\circ} \mathrm{C}$, Jhingran (1991) observed that carps thrive well in the temperature range of $18.3^{\circ} \mathrm{C}$ to $37.8^{\circ} \mathrm{C}$ [51]. Temperature is also suggested to be optimum for the larval development of freshwater fishes. It is reported that the optimum development of $W$. attu is at a temperature range of $28.5^{\circ} \mathrm{C}-30^{\circ} \mathrm{C}[52,53]$. It is quite evident that the duration of larval development of fishes is longer in temperate waters $[54,55] . \mathrm{pH}$ ranges between 7.9 and 8.2 ; however, the values of $\mathrm{pH}$ in the present study are in agreement with the earlier work [49].

Many other chemical parameters such as total hardness, alkalinity, nitrate, phosphate, sulphate, chloride, and magnesium in the culture tanks of Catla fry did not show wide variations. Total alkalinity was significantly greater where organic fertilization and feeds were applied to ponds [9]. Alkalinity increases with organic fertilization because bacterially generated $\mathrm{CO}_{2}$ from manure decomposition dissolves calcium and magnesium carbonate in pond water into calcium and magnesium bicarbonate. In Catla fry rearing tanks, calcium level ranged between 34 and $48 \mathrm{mg} / \mathrm{L}$, which is in agreement with the previous results [9]. Thus, successful hatchery production of fish larvae depends on many factors, the most important being the type of rearing system, physical and chemical parameters, and the type of diet used [9]. However, the values of ammonia recorded in the present experiments showed low level when compared to previous study [49]. Sugiyama and Kawai (1978) reported that higher concentration of dissolved oxygen decreases ammonia level through oxidation [56]. Higher concentration of ammonia 
nitrogen is often noticed in fish culture ponds [57]. Experiment of Pilar Olivar et al. (2000) on sea bass larval rearing illustrated that the survival and growth of reared larvae were a direct function of diet and that the type of rearing system did not adversely affect these parameters [54]. Nevertheless, they point out that unionized ammonia and nitrate are the most dangerous metabolites for fry development and are very important in the first phases of ontogeny and hence should be maintained at a lower level. In the present study, the level of nitrite in the rearing system of Catla fry is lower when compared to the earlier results [49]. Hence, the water quality should be maintained at optimum levels for the normal development of fish fry.

\section{Conclusion}

The results of feeding experiment of Catla fry suggest that Cyclopoid diet can be used as live feed for effective production of fry. The present study suggests that Cyclopoid and Cladoceran can be used as ideal live-feed and its use in the hatchery seed production will lead to sustainable as well as economically viable aquaculture activity.

\section{Conflict of Interests}

The authors declare that there is no conflict of interests regarding the publication of this paper.

\section{Acknowledgments}

The authors are thankful to the Management, Principal, and Head of Department of Zoology, The New College Chennai14 , for providing necessary facilities.

\section{References}

[1] D. Kahan, "Mass cultivation of food organisms in hatcheries problems and proposed solutions," in Proceedings of the Symposium on Coastal Aquaculture, vol. 1, pp. 314-320, 1982.

[2] R. Pourriot, "Les Rotifers-Biology," in Aqua Culture, G. Barnabe, Ed., pp. 201-222, Technique et Documentation, Lavoisier, Paris, France, 1986.

[3] D. Versichele, P. Leger Lavens, and P. Sorgeloos, "Utilization d'Artemia," in Aqua Culture, G. Barnabe, Ed., pp. 239-258, Technique et Documentation, Lavoisier, Paris, France, 1986.

[4] M. Pagano, L. Saint-Jean, R. Arfi, M. Bouvy, and H. Shep, "Population growth capacities and regulatory factors in monospecific cultures of the cladocerans Moina micrura and Diaphanosoma excisum and the copepod T. decipiens from Cote d'Ivoire (West Africa)," Aquatic Living Resources, vol. 13, no. 3, pp. 163-172, 2000.

[5] B. Neelakandan, A. S. Rafiuddin, N. R. Ratish Menon, and N. Kusuma, "Importance of live-food organism in prawn hatcheries-a review," Journal of Indian Fishery Association, vol. 18, pp. 47-67, 1988.

[6] N. Murugan and R. K. Moorthy, "Some trends in culture of cladocera," in Proceedings of the 2nd Indian Fishery Symposium, pp. 33-37, 1990.

[7] K. Altaff, M. B. Raghunathan, R. Suresh Kumar, and S. Moorty, "Harvest of zooplankton live food for ornamental fishes from natural ponds in north Chennai, Tamilnadu," Indian Hydrobiology, vol. 5, pp. 115-118, 2002.

[8] K. Dabrowski and M. Rusiecki, "Content of total and free amino acids in zooplanktonic food of fish larvae," Aquaculture, vol. 30, no. 1-4, pp. 31-42, 1983.

[9] K. Sivakumar, Freshwater fish and prawn larval rearing using indigenous live-feed [Ph.D. thesis], University of Madras, Tamil Nadu, India, 2005.

[10] M. Lauff and R. Hofer, "Proteolytic enzymes in fish development and the importance of dietary enzymes," Aquaculture, vol. 37, no. 4, pp. 335-346, 1984.

[11] E. Holm and D. Moller, "Growth performance of atlantic salmon fed on zooplankton," in Advances in Aquaculture, T. V. R. Lillay and W. A. Dill, Eds., pp. 33-41, Fishing New Books, 1984.

[12] A. Paulraj and K. Altaff, "Survival and growth in postlarvae of Macrobrachium rosenbergii (de Man) on different diets," Pakistan Journal of Scientific and Industrial Research, vol. 42, no. 4, pp. 192-196, 1999.

[13] K. Altaff and M. R. Chandran, "Sex-related biochemical investigation of the diaptomid, Heliodiaptomus viduus Gurney (Crustacea: Copepoda)," Proceedings of Indian Academy of Science, vol. 98, no. 3, pp. 175-179, 1989.

[14] A. Zehra, Breeding biology and culture of fresh water cyclopoid copepod Mesocyclops aspericornis (Daday, 1906) [Ph.D. thesis], University of Madras, Chennai, India, 2000.

[15] R. Sujatha, Breeding Biology and culture of fresh water cyclopoid copepod Cryptocyclops bicolor (Sars, 1863) [Ph.D. thesis], University of Madras, Chennai, India, 2000.

[16] A. Safiullah, Biochemical and nutritional evaluation and culture of freshwater live food organisms for aquahatcheries [Ph.D. thesis], University of Madaras, Chennai, India, 2001.

[17] J. O. Evjemo and Y. Olsen, "Lipid and fatty acid content in cultivated live feed organisms compared to marine copepods," Hydrobiologia, vol. 358, no. 1-3, pp. 159-162, 1997.

[18] A. E. Rutkowska and J. Pijnowska, "morphological fluctuation of planktonic organisms a way alive in changeable habitat," Kosmos, vol. 48, no. 4, pp. 451-463, 1999.

[19] R. H. Peters and J. A. Downing, "Empirical analysis of zooplankton filtering and feeding rates," Limnology \& Oceanography, vol. 29, no. 4, pp. 763-784, 1984.

[20] T. Kiorbae, F. Mohlenbeeg, and H. Nicolojjen, "Ingestion rate and gut clearance in the planktonic copepod Centropages hamatus (Lilleborg) in relation to food concentrations and temperature," Ophelia, vol. 21, pp. 181-194, 1982.

[21] M. M. Friedman and J. R. Strickler, "Chemoreceptors and feeding in calanoid copepods (Arthropeda: Crustacea)," Proceedings of the National Academy of Sciences of the United States of America, vol. 72, no. 10, pp. 4185-4188, 1975.

[22] G. A. Paffenhofer, M. H. Bundy, K. D. Lewis, and C. Metz, "Rates of ingestion and their variability between individual calanoid copepods: direct observations," Journal of Plankton Research, vol. 17, no. 7, pp. 1573-1585, 1995.

[23] R. W. Sterner and K. L. Schulz, "Zooplankton nutrition: recent progress and a reality check," Aquatic Ecology, vol. 32, no. 4, pp. 261-279, 1998.

[24] S. A. Poulet and P. Marsot, "Chemosensory grazing by marine calanoid copepods (Arthropoda: Crustacea)," Science, vol. 200, no. 4348, pp. 1403-1405, 1978.

[25] R. Suresh Kumar, Studies of freshwater cladocerans use as livefood in aquaculture [Ph.D. thesis], University of Madras, Tamil Nadu, India, 2000. 
[26] A. Srivastava, R. M. Rathore, and R. Chakrabarti, "Effects of four different doses of organic manures in the production of Ceriodaphnia cornuta," Bioresource Technology, vol. 97, no. 8, pp. 1036-1040, 2006.

[27] K. Altaff and M. U. Din War, "Culture of Ceriodaphnia cornuta, using chicken manure as fertilizer: conversion of waste product into highly nutritive animal protein," Pakistan Journal of Scientific and Industrial Research, vol. 53, no. 2, pp. 89-91, 2010.

[28] B. B. Jana and G. P. Pal, "The life history parameters of Moina micrura (Kurz.) grown in different culturing media," Water Research, vol. 19, no. 7, pp. 863-867, 1985.

[29] W. D. Russel-Hunter, Biology of Higher Invertebrates, Macmillan, London, UK, 1969.

[30] R. C. Hart, "Zooplankton distribution in relation to turbidity and related environmental gradients in a large subtropical reservoir: patterns and implications," Freshwater Biology, vol. 24, no. 2, pp. 241-263, 1990.

[31] K. Zaleha, B. Ibrahim, B. Akbar John, and B. Y. Kamaruzzaman, "Generation time of some marine harpacticoid species in laboratory condition," The Journal of Biological Sciences, vol. 12, pp. 433-437, 2012.

[32] J. R. B. Alfred, S. Bricice, M. L. Issac et al., "Copepoda," Journal of Madurai University Supplement, vol. 1, A guide to the study of fresh water organisms, pp. 103-151, 1973.

[33] G. Dharani, Reproductive biology and culture of the fresh water plankton Sinodiaptomous (Rhine diaptomous) indicus (Kiefer) (Calanoida: Copepoda) [Ph.D. thesis], University of Madras, Tamil Nadu, India, 1998.

[34] N. A. Hussain and M. Higuchi, "Larval rearing and development of the brown spotted grouper, Epinephelus tauvina (Forskål)," Aquaculture, vol. 19, no. 4, pp. 339-350, 1980.

[35] S. Kraul, H. Ako K, A. Brittain, R. Ogasawara, Cantrell, and T. Nagao, "Comparison of copepods and enriched Artemia as feeds for larval mahimahi, Coryphaena hippurus," Larvi'91-Special publication No. 15 of the European Aquaculture Society, Gent, Belgium, 1991.

[36] R. K. Anderson, P. L. Parker, and A. L. Lawrence, "A C13/C14 tracer study of the utilization of present feed by a commercial important shrimp Penaeus vannamei in a pond grow out system," Journal of World Aquaculture Society, vol. 18, pp. 149-155, 1987.

[37] L. R. D.'Abramo and S. S. Sheen, "Nutritional requirements, feed formulation and feeding practices for intensive culture of the freshwater prawn, Macrobrachium rosenbergii," Reviews in Fishery Science, vol. 2, pp. 1-21, 1991.

[38] P. A. Collins, "Role of natural productivity and artificial feed in the growth of freshwater prawn Macrobrachium borellii (Nobili, 1896) cultured in enclosures," Journal of Aquaculture Tropica, vol. 14, pp. 47-56, 1999.

[39] C. E. Lee, "Rapid and repeated invasions of fresh water by the copepod Eurytemora affinis," Evolution, vol. 53, no. 5, pp. 1423$1434,1999$.

[40] G. Reid, A. W. Bruce, N. Fraser, C. Heinemann, J. Owen, and B. Henning, "Oral probiotics can resolve urogenital infections," FEMS Immunology and Medical Microbiology, vol. 30, no. 1, pp. 49-52, 2001.

[41] O. H. Lowry, N. J. Rosenbrough, A. L. Fair, and R. J. Randall, "Protein measurement with the Folin phenol reagent," The Journal of Biological Chemistry, vol. 193, no. 1, pp. 265-275, 1951.

[42] J. H. ROE, "The determination of sugar in blood and spinal fluid with anthrone reagent," The Journal of Biological Chemistry, vol. 212, no. 1, pp. 335-343, 1955.
[43] J. Folch, M. Less, and G. H. S. Stanley, "A simple method for the isolation and purification of total lipides from animal tissues," The Journal of Biological Chemistry, vol. 226, no. 1, pp. 497-509, 1957.

[44] M. Aliyu-Paiko, R. Hashim, and A. C. Shu-Chien, "Influence of dietary lipid/protein ratio on survival, growth, body indices and digestive lipase activity in Snakehead (Channa striatus, Bloch 1793) fry reared in re-circulating water system," Aquaculture Nutrition, vol. 16, no. 5, pp. 466-474, 2010.

[45] T. V. R. Pillay, Aqualuture-Principles and Practices, Fishing News Books, London, UK, 1990.

[46] T. Nose, "Summary report of the requirement of essential aminoacids for carp," in Fish Nutrition and Fish Feed Technology, pp. 145-156, Heeneman, Berlin, Germany, 1979.

[47] S. Murugesan, V. Sivasubramanian, and K. Altaff, "Nutritional evaluation and culture of freshwater live food organisms on Catla catla," Journal of Algal Biomass Utilization, vol. 1, no. 3, pp. 82-103, 2010.

[48] Y. Bakhtiyar, S. Langer, S. K. Karlopia, and I. Ahmed, "Growth, Survival and proximate body composition of Labeo rohita larvae fed artificial food and natural food organisms under laboratory condition," International Journal of Fisheries and Aquaculture, vol. 3, no. 6, pp. 114-117, 2011.

[49] M. Priyadarshini, J. K. Manissery, B. Gangadhara, and P. Keshavanath, "Influence of feed, manure and their combination on the growth of Cyprinus carpio (L.) fry and fingerlings," Turkish Journal of Fisheries and Aquatic Sciences, vol. 11, no. 4, pp. 597606, 2011.

[50] M. Huet, Textbook of Fish Culture, Fishing News Farnham, Surrey, UK, 1972.

[51] V. G. Jhingran, Fish and Fisheries of India, Hindustan, Delhi, India, 1991.

[52] V. G. Jhingran, Fish and Fisheries of India, Hindustan, Delhi, India, 1983

[53] S. S. Giri, S. K. Sahoo, B. B. Sahu et al., "Larval survival and growth in Wallago attu (Bloch and Schneider): effects of light, photoperiod and feeding regimes," Aquaculture, vol. 213, no. 1-4, pp. 151-161, 2002.

[54] M. Pilar Olivar, P. P. Ambrosio, and I. A. Catalán, "A closed water recirculation system for ecological studies in marine fish larvae: growth and survival of sea bass larvae fed with live prey," Aquatic Living Resources, vol. 13, no. 1, pp. 29-35, 2000.

[55] H. A. Woods, W. Makino, J. B. Cotner et al., "Temperature and the chemical composition of poikilothermic organisms," Functional Ecology, vol. 17, no. 2, pp. 237-245, 2003.

[56] M. Sugiyama and A. Kawai, "Microbiological studies on the nitrogen cycle in aquatic environments. 4. Metabolic rate of ammonium nitrogen in freshwater regions," Bulletin of the Japanese Society of Scientific Fisheries, vol. 44, pp. 351-355, 1978.

[57] P. Edwards, "Inland aquaculture: comments on possible improvements to carp culture in Andhra Pradesh," Aquaculture Asia Magazine, vol. 13, no. 3, pp. 3-7, 2008. 

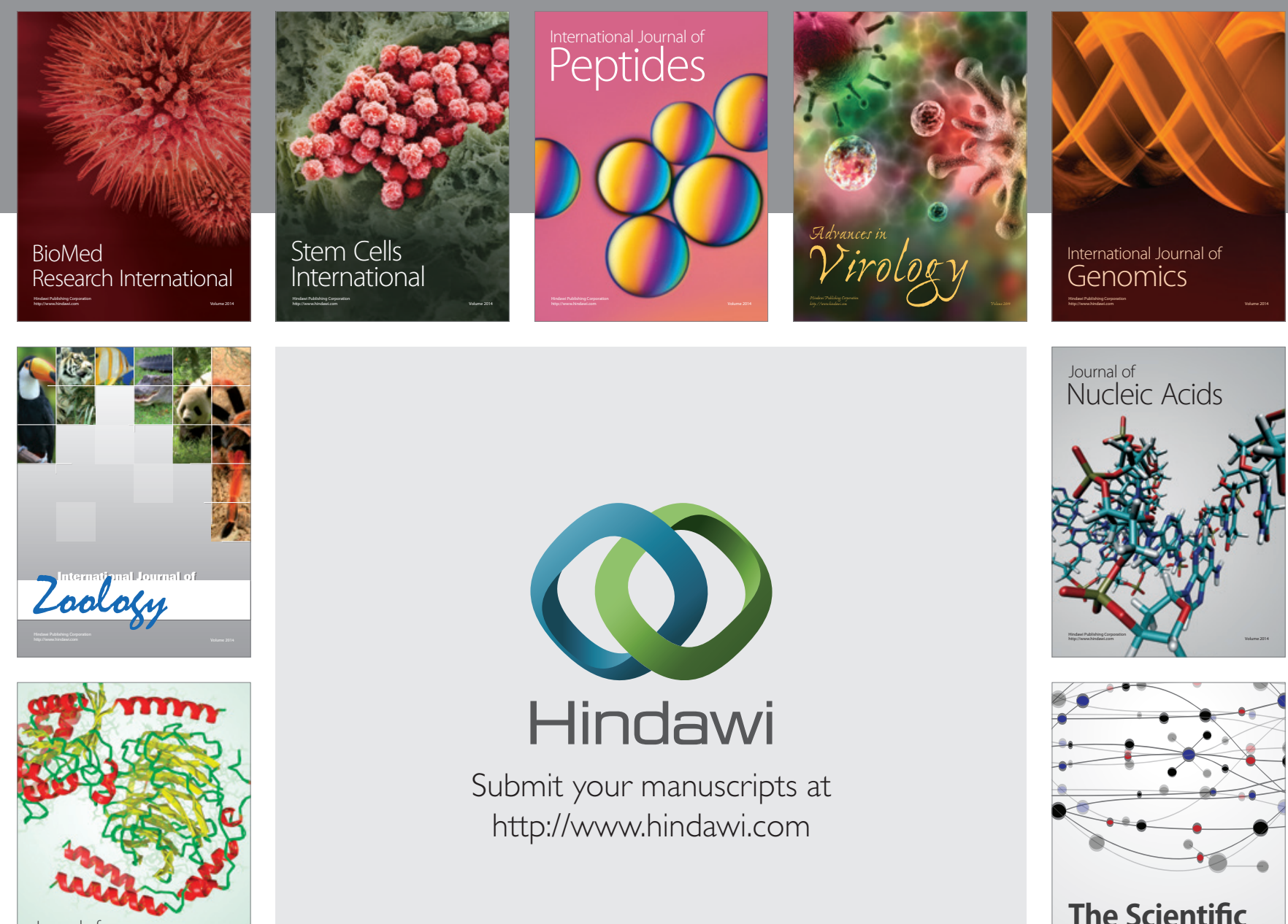

Submit your manuscripts at

http://www.hindawi.com

Journal of
Signal Transduction
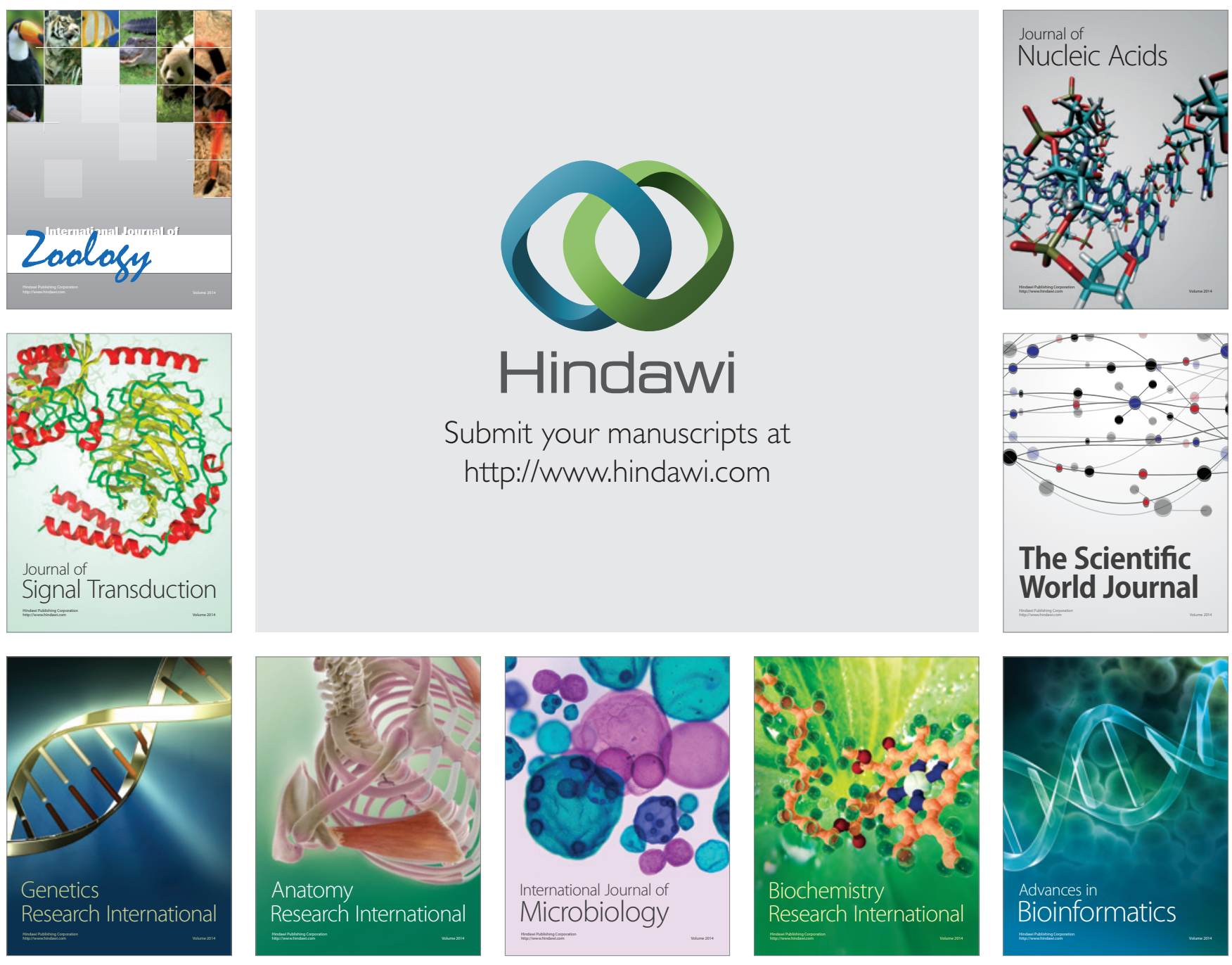

The Scientific World Journal
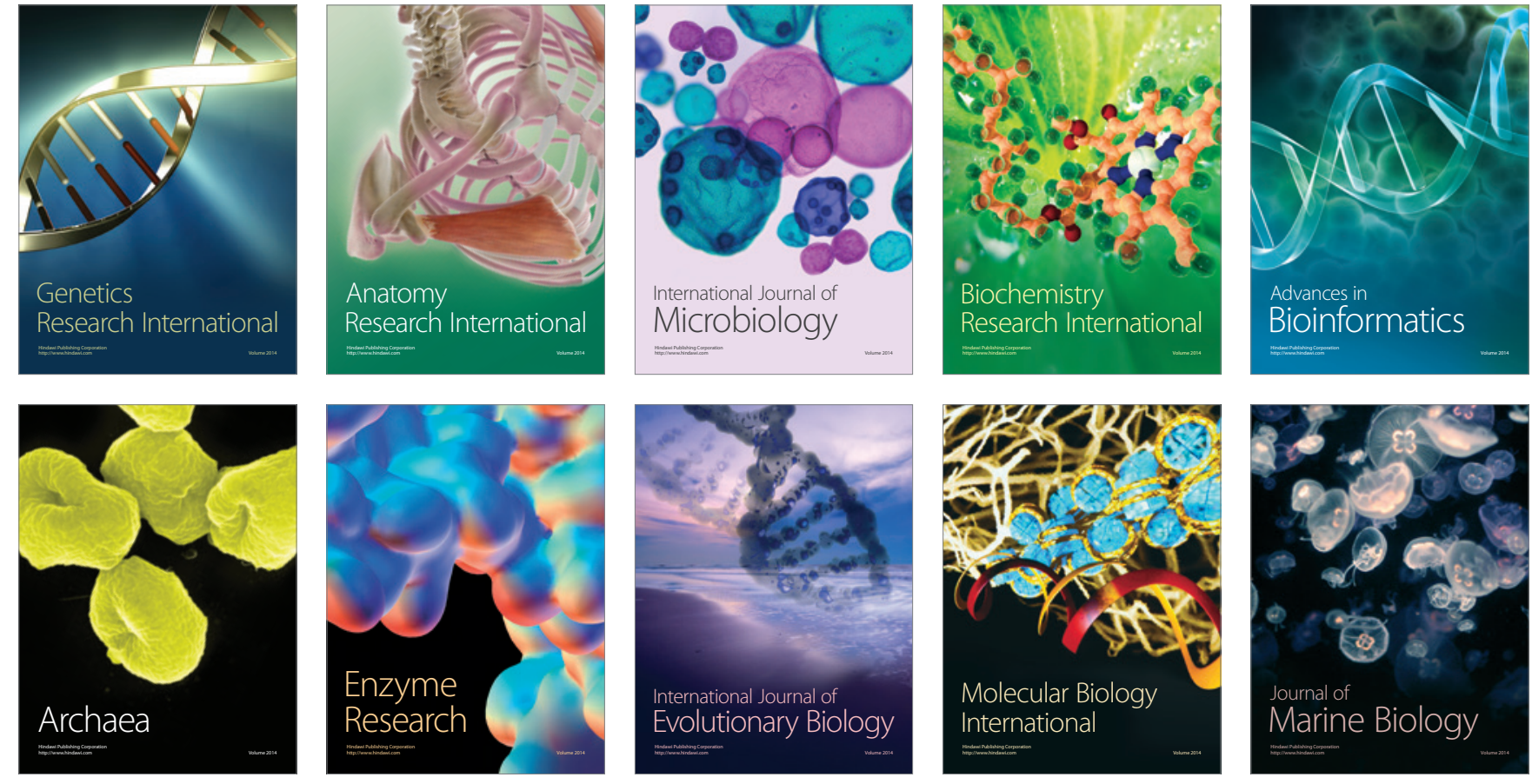